\title{
Voluntary Disclosure, Financial Reporting Quality and Asymmetry Information
}

\author{
Riyanto Setiawan SUHARSONO ${ }^{1}$, Nazief NIRWANTO², Diana ZUHROH ${ }^{3}$
}

Received: September 01, 2020 Revised: October 26, 2020 Accepted: November 16, 2020

\begin{abstract}
This study aims to test Voluntary Disclosure, Quality of Financial Reporting and Information Asymmetry as Moderation Variables. The Voluntary Disclosure variable is calculated using the Index Disclosure. This research uses quantitative methods and uses partial least square with EViews data analysis. The research sample consisted of 225 manufacturing companies listed on the Indonesian stock exchange for the period 20162018. The results of the study state that voluntary disclosure has a positive and significant effect on the quality of financial reporting through asymmetric information. The relationship between voluntary disclosure and asymmetric information has a negative effect on the quality of financial reporting, states that the disclosure of voluntary reports to companies can prevent information asymmetry, as well as the relationship of voluntary disclosure to information asymmetry states that companies that make voluntary disclosure will increase the interest of investors and other stakeholders. The quality of financial reporting states that if there is information asymmetry, the quality of financial reporting will also decline. The low value of relevance will affect the level of large or small information gaps between management and investors. The quality of financial reporting with increased relevance means that asymmetric information will have a negative impact on financial reporting.
\end{abstract}

Keywords: Voluntary Disclosure, Financial Reporting Quality, Asymmetry Information

JEL Classification Code: G14, G32, M41

\section{Introduction}

The information disclosure is understood as a way to implement the transparent process of enterprises to ensure that shareholders and the investors can access information fairly and simultaneously. The information disclosure means that organizations participating in the securities market must be obliged to provide adequate, truthful and timely information relating to their operations or the market to stakeholders. The requirement of investors for information disclosure is becoming increasingly higher, not only in form of mandatory information disclosure, but also in form of voluntary information disclosure (Nguyen, Nguyen, and

${ }^{1}$ First Author and Corresponding Author. Doctoral Student, University of Merdeka Malang, Indonesia [Postal Address: Jalan Terusan Dieng No. 62-64 Klojen, Pisang Candi, Kec. Sukun, Kota Malang, Jawa Timur 65146, Indonesia] Email: rsetiawansuharsono@gmail.com

${ }^{2}$ Professor, University of Merdeka Malang, Indonesia

${ }^{3}$ Lecturer, University of Merdeka Malang, Indonesia

(c) Copyright: The Author(s)

This is an Open Access article distributed under the terms of the Creative Commons Attribution Non-Commercial License (https://creativecommons.org/licenses/by-nc/4.0/) which permits unrestricted non-commercial use, distribution, and reproduction in any medium, provided the original work is properly cited.
Nguyen 2020). Recently, the issue of voluntary disclosure has become a matter of interest to the investors. According to Nguyen and Hoang (2012), voluntary information disclosure is a rather abstract concept, that in addition to the required information to be disclosed according to regulations, the manager must take the initiative in widely publicizing information related to the financial situation, strategic information as well as non-financial information of enterprises.

Voluntary disclosure policy is a trade-off between costs (cost of disclosure) and benefits obtained. Management will disclose information on a voluntary basis if the benefits derived from disclosing the information are greater than the costs. Consistent with the objectives of financial reporting in SFAC No.1, broader disclosure of information is beneficial to users, particularly investors and creditors, in making better investment, credit and other decisions. Investors prefer companies that disclose more information about their company, thus they perceive the risk associated with the company as low. If the company risk is considered low by investors, the required rate of return is also low. Thus the level of capital costs incurred by the company is also low (Tandelilin 2010). So that the cost of capital can be identified as the minimum level of return required by users of equity 
capital on investment. The higher the required rate of return, the higher will be the cost of capital. The requirement of investors for the information disclosure is becoming increasingly higher, not only in mandatory information disclosure, but also in voluntary information disclosure. Recently, the issue of voluntary disclosure has become a matter of more interest to the investors. According to Nguyen and Hoang (2012), voluntary information disclosure is a rather abstract concept, that in addition to the required information to be disclosed according to regulations, the manager must take the initiative in widely publicizing information related to the financial situation, strategic information as well as nonfinancial information of enterprises.

Conflicts arise when managers choose to disclose or not to disclose certain information. Such conflicts usually arise because of unfeasible information that reaches to the public, adequate disclosure will reduce conflicts between owners and managers (Rouf and Harun 2011). Not many companies in Indonesia are announcing their profits by including more detailed voluntary information, most disclosure of information is made on the classification of information that is common and concerns only about the background of the company (Wijantini 2006). The achievement of voluntary disclosure of manufacturing companies listed on Indonesia Stock Exchange is only has an average of $56 \%$. Based on the assessment of the Organization of Economic Cooperation and Development (OECD) score, the average value of disclosure is less than $60 \%$ which indicates that the level of voluntary disclosure stand at a low position (Utama 2012).

Information disclosed by management or the company is one of the factors affecting the cost of equity, namely the level of disclosure. Companies that do not provide an adequate level of disclosure are viewed by some investors as companies with risky financial statements. If the investors assess a highrisk company based on the financial statements produced, the return value expected by investors is also high, which in turn will lead to the high cost of equity that must be issued by the company (Clarkson, Guedes, and Thompson 1996).

Banking companies are expected to provide adequate voluntary disclosure to external parties. Voluntary disclosure will provide useful information for investors and creditors in creating a more rational investment environment (Belkaoui, 2004). Voluntary disclosure is also considered a mechanism to reduce information asymmetry between companies and investors (Akhtaruddin and Haron 2010; Jiang, Habib, and $\mathrm{Hu}$ 2011). Voluntary disclosure reflects management transparency and accountability in carrying out business operations (Akhtaruddin \& Haron 2010; Li, Mangena, \& Pike 2012).

In general, companies only disclose information that is mandatory. The company will consider the costs and benefits that will be obtained when deciding to disclose in full (full disclosure). Companies will only disclose information voluntarily if it is able to provide greater benefits than the costs incurred (Elliot and Jacobson 1994). This is what often causes information asymmetry because companies have more information about their company than shareholders or other stakeholders. The high information asymmetry condition causes shareholders not to have enough information to help them predict the level of risk and return that will be received from their investments. If investors consider a company to be at high risk based on the resulting financial statements, the return on investment expected by investors will also be high, causing the high cost of equity (cost of equity capital).

A quality financial reporting with reliable financial information also influences the efficiency of investment through the availability of information which is more symmetrical between managers and shareholders (Li \& Wang 2010). Financial reporting is the collection and presentation of historical and up-to-date financial information of a company (Drake \& Fabozzi, 2011). Financial reporting is the reporting of financial information on how a company's business is organized (Drake \& Dingler, 2001). Financial reporting is a transaction between two parties, where one party will submit the report to the publisher which controls the preparation (designing) and provision of the reports for the other party, who is the user if the report and evaluates the report to make better financial decisions that is correlated with the whole entity of the party who submits the report for evaluation. Quality financial information is important information in making investment decisions. To maximize its benefit, financial reporting needs to meet the characteristics as a quality financial report. Although the benefits of a financial report requires quality, research results show the fact that financial reports are not always of good quality. These lead to doubt about the quality of the financial reports in general.

Tasios and Bekiaris (2012) have explained that the concept of financial reporting quality is broad and includes financial information, disclosures and non-financial information which is useful for decision making. Certain financial reporting are required to meet the qualitative criteria in order to avoid poor quality and accomplish reviews based on the report. One of the objectives of financial reporting is the fact that it works as a major means of financial information communication to external parties of a company which is used as a basis for decision making of the users (external parties). Financial statement information will have a utility value if it is based on quality financial reporting (Nurcholisah 2016; Tasios and Bekiaris 2012).

Asymmetry information arises when there is a relationship between principal and manager (manager), where the principal (shareholder) delegates tasks and authority to managers. The existence of an important role of a manager in reflecting the company's circumstances in the form of financial statements, will lead to an imbalance of information between managers and stakeholders. This imbalance occurs because managers have 
Riyanto Setiawan SUHARSONO, Nazief NIRWANTO, Diana ZUHROH I

Journal of Asian Finance, Economics and Business Vol 7 No 12 (2020) 1185-1194

enormous access to information in the company compared to stakeholders. This will create a company problem. Lang and Lundholm (1993) suggest that firms that disclose more information have more accurate and less dispersed analysts' earnings forecasts. Boubaker, Gounopoulos, Kallias and Kallias (2016) analyzed how disclosure of management earnings forecasts to investors affects the reliability of available information and investor behavior. Welker (1995) and Healy, Hutton, and Palepu (1999) further verify that firms that provide more disclosures have lower bid-ask spreads, a cost measure related to information asymmetry. Botosan (1997) and Botosan and Plumlee (2002) provide a direct relationship by showing a negative relationship between disclosures in annual reports and the cost of equity capital for firms followed by some analysts and for firms in general. Sengupta (1998) further states that companies with greater disclosure pay lower costs in issuing debt. Baimukhamedova, Baimukhamedova, and Luchaninova (2017) found that firms with higher levels of financial transparency are associated with significantly lower costs of equity capital.

Khanagha (2011) defines value relevance as explanatory power of accounting information to stock price or return. Relevance value is a reflection of an accounting information in this case the financial statements in explaining the state of the company seen in the price or return of shares issued by the company. Seeing the explanation, in this case the manager as the maker of financial statements, which contains accounting information of the company plays an important role to present the reflection and the real state of the company. This is done with the purpose that the stakeholders, especially the investors are not trapped in an information that is not in accordance with the actual circumstances of the company.

Decourt et al. (2019) aimed to build an index of informational asymmetry with market and firm proxies that reflect the analysts' perception of the level of informational asymmetry of companies. Their proposed method consisted of the construction of an algorithm based on the Elo rating and captured the perception of the analysts who choose between two firms based on the firm providing better information. After building the informational asymmetry index, they ran a regression model to measure the factors that affect the level of informational asymmetry of a company. They found four significant variables: coverage, volatility, Tobin's Q, and size. Abd (2016) examined the implications of the problem of information asymmetry at the level of the financial markets, by researching the impact of information associated with investment decision-making asymmetrically distributed on the efficiency of the way the financial markets work. The study concluded that the information asymmetry available to investors is often reflected in the asymmetry of sellers and investors' expectations of the financial assets.

Evidence of the low quality of financial reporting in Indonesia is that there are still several companies that have not submitted their financial reports in a timely manner. Based on stock exchange records up to April 30, 2013, of the 469 companies listed on the Indonesia Stock Exchange (IDX) there are still 70 companies or around $14.93 \%$ of listed companies that have not submitted their annual reports for 2012. Of the 70 companies, 1 listed company which submitted information disclosure was late in submitting annual financial reports, 55 listed companies did not submit information on causes of delay in submitting annual reports, $5 \mathrm{KIK}$ mutual fund companies were not required to submit annual financial reports, 6 listed companies were not required to submit annual reports for 2012 (financial year ends per March, May and September), and 3 listed companies referred to the provisions of Bapepam dan LK No. X.K.6 number $1 \mathrm{~b}$ (www.idx.co.id).

Based on the assessment of the Indonesian Institute of Accountants on May 4, 2018, it was also stated that the quality of financial reporting in Indonesia was low. The Indonesian Institute of Accountants has a standard of up to five levels for reporting quality, and companies in Indonesia are still at the third level. This results in the potential for fraud and corruption of corporate financial reports in Indonesia. The Indonesian Institute of Accountants encourages auditors to always monitor and conduct audits of financial reporting. This is to make sure that the quality of financial reporting can run well (www.repubika.com).

Previous research has shown a significant relationship between disclosure and financial reporting quality as indicated by the value relevance of the information disclosed (Pavlopoulos et.al, 2019; Lee and Yeo, 2016; Bernardi and Stark, 2018; Zhou et al., 2017). Cases regarding the lack of disclosure and poor financial reporting quality occur in many manufacturing companies in Indonesia, shown by the Toshiba Company in May 2015, where an investigation into the internal accounting scandal and revision of profit calculations in the last 3 years and found 1 accounting fraud. 22 billion US dollars (www.integrity-indonesia.com, 9/14/2017). Anomalies also occurred in Garuda Indonesia's Financial Statements, which began with the company's financial statements which recorded a net profit of US $\$ 809,846$ in 2018 or the equivalent of Rp. 11.49 billion (exchange rate Rp. 14,200 / US \$).

This study also examines the relationship between information asymmetry and the quality of financial reporting. Moerman's (2006) research shows a relationship between information asymmetry and financial reporting quality. The lower the information asymmetry, the better the quality of financial reporting will be. Vice versa, the higher the information asymmetry, the lower the quality of financial reporting). This study combines the measurement of information asymmetry with the proxy bid-ask spread in Cohen's (2003) study. Research by Behadili et al. (2019) shows the negative effect between information asymmetry 
and the quality of financial reporting. Research by Bushman and Smith (2001), Healy and Palepu (2001), Biddle and Hilary (2006), and Lambert et al. (2007) showed a negative relationship between the quality of financial reporting and the problem of information asymmetry in decision making by investors.

\section{Literature Review}

\subsection{Variable Voluntary Disclosure}

Disclosure means providing useful data to those who need it. In financial reports, disclosure means that financial reports must provide sufficient information and explanation regarding the results of activities of a business unit. The information disclosed must be useful and not confuse users of financial statements in assisting economic decision making (Chariri, 2001). Evans (2003) defines disclosure as providing information needed for financial statements, records and also supporting evidence for these financial statements. Management statements in newspapers and other information in the mass media are not included in the category of disclosure. Wolk et al. (2001) describes information in financial reports, notes, supporting evidence as well as segmental financial statements and statements that reflect price changes as part of disclosures, including operating analysis for the coming year, financial forecasts, and additional financial statements. Meek et al. (1995) revealed that voluntary disclosure is disclosure of information that exceeds what is required because it is considered relevant to the needs of users of financial statements.

Voluntary Disclosure is the presentation of financial statement information other than those required in the provisions including in this case supporting disclosures relating to financial statements, notes related to financial statements, and other information within the company that has a direct or indirect impact on the company (Riahi and Belkaoui, 2006). Voluntary disclosure is also one way to increase the credibility of corporate financial reports and to assist investors in understanding the company's business strategy (Healy and Palepu, 1995). So that with the voluntary disclosure of financial statement users, the information will be more complete in understanding the operational activities of public companies. In addition, the existence of voluntary disclosures further shows the transparency of the company. According to Eliot and Jacobson (1994), a company will only disclose information voluntarily if it is able to provide greater benefits than the costs incurred.

This study aims to examine voluntary disclosure and financial reporting quality with information asymmetry as a moderating variable. The research phenomenon related to the quality of financial reporting is usually manifested in company profits earned in the current year. Benchmarks of the profit generated by a company in its future operations will indicate the existence of a high quality corporate financial reporting (Cohen, 2003). Financial reporting is said to be of high quality if the current year's earnings can be a good indicator of the company's future earnings (Lev and Thiagarajan 1993; Penman and Zhang 2002; Richardson et al. 2001; Beneish and Vargus 2002; Richardson 2003), or is strongly associated with future operating cash flows (Dechow and Dichev 2002; Cohen 2003).

\subsection{Variable Financial Reporting Quality}

The quality of financial reporting is the result or process of accountability for the company's financial reporting, which is measured based on the existing standards and through examinations that meet the principles of financial reporting, namely understandability, relevance, reliability and comparability and consistency (Suharsono 2018; Arens 2001). Research on financial reporting quality can be carried out using two approaches (Cohen, 2003; Francis et al. 2004). The first approach is research related to examining what factors cause the quality of financial reporting to be produced, and the second approach is the extent to which the users of financial statements respond to the quality of financial reporting. A condition in which some investors have information and others do not or a situation where management as the party has more control over the information than the investors/creditors. Certain parties related to the company do not have the same information about the prospects and risks of the company, certain parties have better information than outsiders (Behadili et al. 2019; Bushman and Smith 2001; Healy and Palepu 2001; Biddle and Hilary 2006; Lambert et al. 2007).

\subsection{Variable Asymmetry Information}

According to Scott (2006), there are two forms of information asymmetry, namely: (1) Adverse selection, a type of information asymmetry in which one or more parties involved in a business transaction, or potential transaction, have information advantages compared to other parties; (2) Moral hazard, a type of information asymmetry in which one or more parties involved in a business transaction, or potential transaction, can observe their actions in completing the transaction, while the other party cannot. Information asymmetry is a condition that shows that some investors have information and others do not have it or management is more in control of the information than investors/creditors (Jogiyanto (2010). According to Moerman (2006), research shows that there is a relationship between information asymmetry and the quality of financial reporting. The lower the information asymmetry, the better the quality of financial reporting. Conversely, the higher the information asymmetry, the lower the quality of financial reporting. This study combines the measurement of information asymmetry 
with the proxy bid-ask spread in Cohen's (2003) research. It shows that good disclosure is related to the quality of financial reporting in South Africa (Pavlopoulos et al., 2019; Lee and Yeo, 2016; Bernardi and Stark, 2018; Zhou et al., 2017; Lee and Yeo, 2016). Moerman (2006) showed a relationship between information asymmetry with the quality of financial reporting. The lower the information asymmetry, the better the quality of financial reporting will be. Vice versa, the higher the information asymmetry, the lower the quality of financial reporting.

Previous research has also shown a significant relationship between voluntary disclosure and information asymmetry (Rodrigues, et al., 2015; Farmer and Pecorino, 2013; Pour and Imanzadeh, 2017; Shroff, et al, 2013; Chiyanchantan, 2013; Peterson and Plenborg, 2006). Information asymmetry between companies and potential investors can be caused by a low level of disclosure, an increase in the cost of capital due to adverse selection between the buyers and the sellers. Leuz and Verrechia (2000) also investigated the relationship between voluntary disclosure and stock liquidity. To obtain stock liquidity information, sometimes companies improve the quality of disclosure by reducing information asymmetry. Voluntary disclosure is one way for potential investors to get information about a company. Based on the research of Denis and McConnell (2003) in Spain and Portugal, it presents a good environment for examining the relationship between voluntary disclosure and assimilation of information. It shows that there is a motive for corporate disclosure to reduce information asymmetry between company management and outside investors.

\section{Methodology}

This study uses the Slovin's formula and produced a sample of 225 manufacturing companies listed on the Indonesia Stock Exchange from 2016 to 2018. This study uses the Voluntary Disclosure variable as a presentation of financial statement information outside those required in the provisions including in this case the supporting disclosures related to financial reports, notes related to financial reports, and other information within the company that has a direct or indirect impact on the company (Suwarjono, 2008; Riahi and Belkaoui, 2006). This study uses the information asymmetry variable to show the conditions that show some investors have information and others do not have or management as the party who has more control over information than investors/ creditors (Jogiyanto 2010; Suwarjono 2014; Hanafi 2014). This study uses the variable quality of financial reporting as a result or an accountability process for corporate financial reporting which is measured based on existing standards and thorough examinations that meet the rules. From the Financial Statements, which are understandable, relevant, reliable and comparative and have consistency (Suharsono 2018; Arens 2001).

\section{Results and Discussion}

\subsection{Classic Assumption Test}

Before the path analysis is carried out, first the assumption tests that underlie the path analysis are carried out, namely the residual normality assumption.

\subsection{Normality Test}

The regression model can be said to meet the normality assumption if the residuals obtained from the regression model are normally distributed. The hypothesis used in the test is:

H0: The residual distribution is normally distributed

H1: The residual distribution is not normally distributed

To test this assumption, a histogram graph and the JarqueBera test can be used as follows:

From the test using Jarque-Bera, it was found that the probability or significance value of each model was greater than $\alpha(0.05)$, so a decision was made to accept $\mathrm{H} 0$, which means that the residual distribution is normally distributed (assumptions are met).

\subsection{Path Analysis}

The calculation of the path coefficient in this study uses standardized regression analysis by looking at the effect simultaneously and partially on each equation. The method used is the least square (LS), the least squares method is calculated using Eviews software. The results of the regression test are shown in the table below:

Based on table 2 above, it can be concluded that:

Table 1: Jarque-Fallow Test

\begin{tabular}{|l|c|c|}
\hline Residual & Jarque-Bera & Probability \\
\hline Model 1 & 2.748 & 0.253 \\
\hline Model 2 & 3.671 & 0.160 \\
\hline
\end{tabular}

Table 2: Simultaneous $\mathrm{F}$ test results

\begin{tabular}{|c|c|c|c|c|}
\hline Model & F count & $\begin{array}{c}F \\
\text { tabel }\end{array}$ & $\begin{array}{c}\text { p-value } \\
F\end{array}$ & Description \\
\hline Model 1 & 5.714 & 3.037 & 0.004 & Signifikan \\
\hline Model 2 & 2.112 & 2.645 & 0.100 & $\begin{array}{l}\text { Tidak } \\
\text { signifikan }\end{array}$ \\
\hline \multicolumn{5}{|c|}{ R square model $1=0.049$} \\
\hline \multicolumn{2}{|c|}{ R square model 2} & $=0.028$ & & \\
\hline
\end{tabular}


Model 1 has an F count value of 5,714 with a p-value of 0.004 . Because the calculated $\mathrm{F}$ value is greater than the $\mathrm{F}$ table or the $\mathrm{p}$-value is smaller than $\alpha 5 \%$, it can be concluded that in the first model, the exogenous variable Voluntary Disclosure has a significant effect on the endogenous variable Information Asymmetry. Model 2 has an F count of 2,112 with a p-value of 0.100 . Because the calculated $\mathrm{F}$ value is smaller than the $\mathrm{F}$ table or the p-value is greater than $\alpha 5 \%$, it can be concluded that in model 2, the exogenous variable Voluntary Disclosure and Information Asymmetry Variables have a significant effect on the endogenous variables of Financial Reporting Quality.

\subsection{Hypothesis Testing}

Based on Table 3, it can be concluded that:

From the value of R Square shows a value of 0.049 or 4.9\%. This means that the Information Asymmetry variable is explained by the independent variable of Voluntary Disclosure, while the remaining $95.1 \%$ is influenced by other variables outside the independent variables studied.

Standardize regression equation:

$$
\mathrm{Y}=0.140 \mathrm{X} 1+\varepsilon \mathrm{i}
$$

From the $t$ value shows that:

The Voluntary Disclosure variable has a positive and significant effect on the Information Asymmetry variable. By having the value $\mid t$ count $\mid$ which is greater than $t$ table $(2.098>$ $1.971)$ or the $p$-value $t$ is smaller than $\alpha(0.037<0.050)$. The positive coefficient obtained indicates that the increase in the Voluntary Disclosure variable can significantly increase the Information Asymmetry variable.
Based on Table 4, it can be concluded that:

From the value of $\mathrm{R}$ Square shows a value of 0.028 or $2.8 \%$. This means that the variable Z (Financial Reporting Quality) is explained by the variables $X$ (Voluntary Disclosure) and $\mathrm{Y}$ (Information Asymmetry) of 2.8\%, while the remaining $97.2 \%$ is influenced by variables outside the independent variables studied. The $t$ count value shows that:

a) The Voluntary Disclosure variable has a negative and insignificant effect on the Quality of Financial Reporting variables. By having the value $\mid \mathrm{t}$ count $\mid$ which is smaller than $t$ table $(1.061<1.971)$ or the $\mathrm{p}$-value $\mathrm{t}$ is greater than $\alpha(0.290>0.050)$. The negative coefficient obtained indicates that an increase in the variable $X$ Voluntary Disclosure can reduce the Financial Reporting Quality variable but it is not significant.

b) The Information Asymmetry variable has a negative and insignificant effect on the variable of Financial Reporting Quality. By having the value $\mid \mathrm{t}$ count $\mid$ which is smaller than $t$ table $(0.056<1.971)$ or the $\mathrm{p}$-value $\mathrm{t}$ is greater than $\alpha(0.955>0.050)$. The negative coefficient obtained indicates that an increase in the Information Asymmetry variable can reduce the Financial Reporting Quality variable but it is not significant.

From the results of the analysis that has been carried out, it is followed by testing the Goodness of Fit model using the total coefficient of determination. The total diversity of data that can be explained by the model is measured by the formula:

Table 3: Results of regression

\begin{tabular}{|l|c|c|c|c|}
\hline Variable & Beta Coefficient & $\mathbf{t}$ & p-value & Description \\
\hline Voluntary Disclosure & 0.140078 & 2.098259 & 0.0370 & Significance \\
\hline $\mathrm{t}_{(0.05,22)}$ & $=1.971$ \\
R Square & $=0.049$ \\
\hline
\end{tabular}

Table 4: Results of regression

\begin{tabular}{|l|c|c|c|c|}
\hline Variabel & Beta Coefficient & $\mathbf{t}$ & $\mathbf{p}$-value t & Description \\
\hline Voluntary Disclosure & -0.072492 & -1.061134 & 0.2898 & Significance \\
\hline Information Asymmetry & -0.003838 & -0.056429 & 0.9551 & Significance \\
\hline $\mathrm{t}_{(0.05,21)}$ & $=1.971$ \\
\hline R Square & $=0.028$ \\
\hline
\end{tabular}


Riyanto Setiawan SUHARSONO, Nazief NIRWANTO, Diana ZUHROH I

Journal of Asian Finance, Economics and Business Vol 7 No 12 (2020) 1185-1194

Table 5: Hypothesis Testing Results of Indirect Effect

\begin{tabular}{|l|c|c|c|c|}
\hline $\begin{array}{l}\text { Independent } \\
\text { Variable }\end{array}$ & Intermediate Variable & Dependent variable & Indirect coefficient & Description \\
\hline $\mathrm{X}$ & $\mathrm{Y}$ & $\mathrm{Z}$ & -0.00054 & No Significance \\
\hline
\end{tabular}

$$
\mathrm{R} 2 \mathrm{~m}=1 \text { - P2e1 P2e2.P2ep }
$$

Where,

$$
\mathrm{P} 2 \mathrm{e} 1=1 \text { - R21; P2e2 = } 1 \text { - R22. }
$$

Where $\mathrm{R} 21$ is $\mathrm{R}$ square for equation 1 which is equal to 0.049 , R22 is R square for equation 2 which is equal to 0.028 :

$$
\mathrm{P} 2 \mathrm{e} 1=1-0.049=0.951 ; \mathrm{P} 2 \mathrm{e} 2=1-0.028=0.972 .
$$

So that the total coefficient of determination is obtained as follows:

$$
\mathrm{R} 2 \mathrm{~m}=1-(0.951 \times 0.972)=0.076 \text { or } 7.6 \%
$$

The results of the $\mathrm{R} 2 \mathrm{~m}$ calculation indicate that the diversity of data that can be explained by the model is 0.076 or in other words, the information contained in the $7.6 \%$ data can be explained by the model. Meanwhile, $92.4 \%$ of the remaining diversity is explained by other variables (which are not included in the model).

Overall, the model in this study is divided into 5 direct effects and 2 indirect effects. Table 5 presents the results of the indirect effect test:

The results of testing the first hypothesis indicate that Voluntary Disclosure has a positive and significant effect on the Quality of Financial Reporting. This indicates that the higher the level of disclosure, the more information is disclosed by the company and shows that there is nothing to hide in the company's annual financial statements, it will reduce information asymmetry, thereby reducing the cost of capital. The results of this test support previous research from Pavlopoulos et al (2019) which states that the level of disclosure will increase if the company increases the information in its financial statements. The results of this study also support research from Mahboub (2017) which shows the quality of financial reports increases by expanding existing information. This study also supports previous research from Kribat and Crawford (2013) and Jalil and Tanewski (2015) which shows that the number of items disclosed affects the company's financial statements.
The results of testing the second hypothesis indicate that Voluntary Disclosure has a positive and significant effect on Information Asymmetry. The results of the study stated that the higher the level of voluntary disclosure, the more information disclosed by the company so that it shows that there is nothing hidden in the company's annual report. A high level of disclosure implies a low level of information asymmetry between management and investors and other stakeholders. The results of this test support previous research from research by Alves (2015), Farmer (2013), Pour and Imanzadeh (2017) and Shroff (2013) which shows a relationship between voluntary disclosure and information asymmetry. The greater the voluntary disclosure made, the smaller the information asymmetry, and vice versa, the smaller the voluntary disclosure, the greater the information asymmetry.

The results of testing the third hypothesis indicate that information asymmetry has a negative and significant effect on the quality of financial reporting. The results of this test supports previous research from Moerman's (2006) study showing a relationship between information asymmetry and the quality of financial reporting. The lower the information asymmetry, the better the quality of financial reporting will be. Vice versa, the higher the information asymmetry, the lower the quality of financial reporting. This study also supports previous research from Cohen (2003) which combines the measurement of information asymmetry with the proxy bid-ask spread.

The results of testing the fourth hypothesis indicate that Voluntary Disclosure has a negative and significant effect on the Quality of Financial Reporting with Information Asymmetry as a moderating variable. The results of this test support previous research showing a significant relationship between disclosure and financial reporting quality, which is indicated by the value relevance of the information disclosed. (Pavlopoulos et al., 2019). Kribat and Crawford (2013). Jalil and Tanewski (2015). Mahboub (2017). Meanwhile, research by Alves (2015), Farmer (2013), Pour and Imanzadeh (2017) and Shroff (2013) shows a relationship between voluntary disclosure and information asymmetry, where the greater the voluntary disclosure made, the smaller the information asymmetry, and vice versa, the smaller the voluntary disclosure, the greater the information asymmetry. 


\section{Conclusion}

Based on the results of research on Voluntary Disclosure, Quality of Financial Reporting and Asymmetric Information as Moderating Variables (Evidence from the Indonesia Stock Exchange). This study reveals that the voluntary disclosure relationship has a negative effect on the quality of financial reporting, and with the disclosure of voluntary reports, the companies can avoid information asymmetry. It also states the relationship between voluntary disclosure and information asymmetry, which reveals that the more companies make voluntary disclosures, more will be the interest of investors and stakeholders. Information asymmetry on the quality of financial reporting states that if there is information asymmetry for the company, the quality of financial reporting will also decline. The low value of high corporate relevance affects the level of large or small information gaps between management and investors (information asymmetry). The quality of financial reporting, such as increasing value relevance, decreasing asymmetric information, or in other words, the quality of accounting information conveyed through financial reporting has a negative impact on asymmetric information. This is supported by Fanani, who shows the relevance of information value which has a negative effect on asymmetric information.

\section{References}

Akhtaruddin, M., \& Haron, H. (2010). Board Ownership, Audit Committees' Effectiveness, and Corporate Voluntary Disclosures. Asian Review of Accounting, 18(3).

Arens, A. A., \& Loebbecke, J. (2001). Integrated Approach Auditing. ( $9^{\text {th }}$ ed.). Jakarta, Indonesia: Salemba Empat.

Baimukhamedova, A., Baimukhamedova, G., \& Luchaninova, I. (2017). Financial Disclosure and the Cost of Equity Capital: The Empirical Test of the Largest Listed Companies of Kazakhstan. Journal of Asian Finance, Economics and Business, 4(3), 5-17. http://dx.doi.org/10.13106/jafeb.2017.vol4.no3.5

Behadilli, et al. (2019). Information Asymmetry, Financial Reporting Quality, and Investment's Efficiency: Evidence from Iraq. Journal of Engineering and Applied Sciences 14(16), 5869-5874.

Belkaoui, A. R. (2006). Accounting Theory: Accounting Theory (5th ed.). Jakarta, Indonesia: Four Salemba.

Beneish, M., \& Vargus, M. (2002). Insider Trading, Earning Quality, and Accrual Mispricing. The Accounting Review, 77(4), 755-791.

Botosan, C. (2006). Disclosure and the Cost of Equity Capital. What Do We Know? Accounting and Business Research, International Accounting Policy Forum, 31-40.

Botosan, C. A., \& Plumlee, M. A. (2002). A reexamination of disclosure level and expected cost of equity capital. Journal of Accounting Research, 40, 21-40.
Boubaker S., Gounopoulos D., Kallias A., \& Kallias K. (2016). Management earnings forecasts and IPO performance: Evidence of a regime change. Review of Quantitative Finance and Accounting, 1-39.

Chan, K., L. Chan, N. Jegadeesh, \& Lakonishok, J. (2004). Earnings quality and stock returns. Working Paper, University of Illinois at Urbana-Champaign.

Clarkson, P., Guedes, J., \& Thompson, R. (1996). On the Diversification, Observability, and Measurement of Estimation Risk. The Journal of Financial and Quantitative Analysis, 31(1), 69-84. https://doi.org/10.2307/2331387

Cohen, D. A. (2003). Quality of Financial Reporting Choice: Determinants and Economic Consequences. Working Paper. Northwestern University Collins.

Cohen, D. A., (2003). Does Information Risk Really Matter? An Analysis of the Determinant and Economic Consequences of Financial Reporting Quality. Working Paper. Northwestern University Collins.

Dechow P. \& Dichev. (2002). The Quality of Accruals and Earnings: The Role of Accrual Estimation Errors. The Accounting Review, 77, 35-59.

Denis, D. K., \& and McConnell, J. J. (2003). International Corporate Governance. University of Pittsburgh - Katz School of Business.

Drake, S. M., \& Dingler, R. G. (2001). The practical guide to finance and accounting. Upper Saddle River, NJ: Prentice Hall.

Fabozzi, F. J., \& Drake, P. P. (2011). Finance: Capital Markets, Financial Management, and Investment Management. Hoboken, NJ: John Wiley \& Sons, Inc

Elliot, R. K., \& Jacobson, P. D. (1994). Costs and Benefits of Business Information. Accounting Horizons, 8, 80-96.

Evans, T. G. (2003). Accounting Theory. Contemporary Accounting issue. Cincinnati, $\mathrm{OH}$ : South Western Publishing.

Farmer, A., \& Pecorino, P. (2013). Discovery and Disclosure with Asymmetric Information and Endogenous Expenditure at Trial. Journal of Legal Studies, 42(1).

Francis, J., LaFond, R., Olsson, P., \& Schipper, K. (2004). Costs of Equity and Earnings Attributes. The Accounting Review, 79(4), 967-1010.

Healy, P. M., \& Palepu, K. G. (2001). Information asymmetry, corporate disclosure, and the capital markets: A review of the empirical disclosure literature. Journal of Accounting and Economics, 31, 405-440.

Jiang, H., Habib, A., \& Hu, B. (2011). Ownership Concentration, Voluntary Disclosures and Information Asymmetry in New Zealand. British Accounting Review, 43(1).

Jogiyanto. (2010). Portfolio Theory and Investment Analysis. Seventh Edition. BPFE. Yogyakarta.

Khanagha, J. B. (2011). Value Relevance of Accounting Information in the United Arab Emirates. International Journal of Economics and Financial Issues. 
Kribat, \& Crawford, L. (2013). Evidence on the nature, extent and determinants of disclosures in Libyan banks' annual reports. Journal of Accounting in Emerging Economies, 3(2).

Lang, M., \& Lundholm, R. (1993). Cross-sectional determinations of analyst ratings of corporate disclosure. Journal of Accounting Research, 31(2), 246-271.

Leuz, C., \& Verrecchia, R. (2000). The Economic Consequences of Increased Disclosure. Journal of Accounting Research, 38, 91-124.

Lev. B., \& Thiagarajan, S. R. (1993). Fundamental Information Analysis. Journal of Accounting Research, 31(2), 190-215.

Meek, G. K., Roberts, C. B., \& Sidney, J. G. (1995). Factors Influencing Voluntary Annual Report Disclosures by U.S., U.K. and Continental European Multinational Corporations. Journal of International Business Studies, 26, 555-572. https:// doi.org/10.1057/palgrave.jibs.8490186

Moerman, D. E. (2006). The Role of Information Asymmetry and Financial Reporting Quality in Debt Trading: Evidence from the Secondary Loan Market. Journal of Accounting and Economics, 46(2-3), 240-260. https://doi.org/10.1016/j. jacceco.2008.08.001

Nguyen, T. M. H., Nguyen, N. T., \& Nguyen, H. T. (2020). Factors Affecting Voluntary Information Disclosure on Annual Reports: Listed Companies in Ho Chi Minh City Stock Exchange. Journal of Asian Finance, Economics and Business, 7(3), 53-62. https://doi.org/10.13106/jafeb.2020. vol7.no3.53

Nurcholisah, K. (2016). The Effect of Financial Reporting Quality on Information Asymmetry and Its Impacts on Investment Efficiency. International Journal of Economics, Commerce and Management, 4(5), 838-850.

Pavlopoulos, A., Magnis, C., \& Latridis, G. E. (2019). Integrated Reporting an Accounting Disclosure Tool for Substantial Financial Reporting and its Effects on a firm's Market Valuation. Research in International Business and Finance, 49, 13-40. DOI: 10.1016/j.ribaf.2019.02.007

Penman, H. P., \& Zhang, X. J. (2002). Accounting Conservatism, the Quality of Earnings, and Stock Returns. The Accounting Review, 77, 237-264.

Peterson, C., \& Plenborg, T. (2006). Voluntary Disclosure and Information Asymmetry in Denmark. Journal of
International Accounting, Auditing and Taxation, 15, 127-149. http://dx.doi.org/10.1016/j.intaccaudtax.2006.08.004

Richardson, S. (2003). Earnings Quality and Short Sellers. Accounting Horizons, 17, 49-61.

Richardson, S., Sloan, R., Soliman, M., \& Tuna, I. (2001). Information in Accruals About the Quality of Earnings. Working Paper, University of Michigan Business School.

Rouf, M. A., \& Harun, M. A. (2011). Ownership Structure and Voluntary Disclosure in Annual Reports of Bangladesh. Pakistan Journal of Commerce and Social Sciences, 5(1),129-39.

Scott., A. J. (2006). Creative Cities: Conceptual Issues And Policy questions. Journal of Urban Affaires, 28(1), 1-17. https://doi. org/10.1111/j.0735-2166.2006.00256.x

Sengupta, P. (1998). Corporate Disclosure Quality and the Cost of Debt. The Accounting Review, 73(10), 459- 474.

Shroff, (2015). Real Effects of Financial Reporting Quality and Credibility: Evidence from the PCAOB Regulatory Regime. Working Paper.

Suharsono, R.S. (2018). Audit Quality, Debt Default, and Company Growth on Acceptance of Going Concern Audit Opinions. Scientific Journal of Accounting, Finance and Taxation, 2(1), 35-47.

Tasios, S., \& Bekiaris, M. (2012). Auditor's Perceptions of Financial Reporting Quality: The Case of Greece. International Journal of Accounting and Financial Reporting, 2, 57-74.

Utama, C. A. (2012). Company Disclosure in Indonesia: Corporate Governance Practice, Ownership Structure, Competition and Total Assets. Asian Journal of Business and Accounting, 5(1).

Welker, M. (1995). Disclosure policy, information asymmetry and liquidity in equity markets. Contemporary Accounting Review, $11(2), 153-174$.

Wijantini, W. (2006). Voluntary Disclosure in the Annual Reports of Financially Distressed Companies in Indonesia. Gadjah Mada International Journal of Business, 8(3).

Wolk T., \& Dodd, J. L. (2001). Accounting theory; A conceptual Institutional Approach ( $5^{\text {th }}$ ed.). Cincinnati OH: South-Western College Publishing.

Yao, L. (2016). Corporate Governance and Voluntary Disclosure in Corporate Annual Reports of Malaysian Listed Firms, Working Paper. 
